\title{
Behavior of Online Prosumers in Organic Product Market as Determinant of Sustainable Consumption
}

\author{
Magdalena Maciaszczyk ${ }^{1, *(D)}$ and Maria Kocot ${ }^{2}$ \\ 1 Department of Strategy and Business Planning, Faculty of Management, Lublin University of Technology, \\ 20-618 Lublin, Poland \\ 2 Department of Economic Informatics, University of Economics in Katowice, 40-287 Katowice, Poland; \\ maria.kocot@ue.katowice.pl \\ * Correspondence: m.maciaszczyk@pollub.pl
}

Citation: Maciaszczyk, M.; Kocot, M. Behavior of Online Prosumers in Organic Product Market as Determinant of Sustainable Consumption. Sustainability 2021, 13, 1157. https://doi.org/10.3390/ su13031157

Academic Editor: Flavio Boccia

Received: 1 December 2020

Accepted: 18 January 2021

Published: 22 January 2021

Publisher's Note: MDPI stays neutral with regard to jurisdictional claims in published maps and institutional affiliations.

Copyright: (C) 2021 by the authors. Licensee MDPI, Basel, Switzerland. This article is an open access article distributed under the terms and conditions of the Creative Commons Attribution (CC BY) license (https:// creativecommons.org/licenses/by/ $4.0 /)$.

\begin{abstract}
The article focuses on the specificity of the behavior of modern prosumers in the market for organic products as a determinant of sustainable consumption. The strengthening of the proconsumer relationship is made possible thanks to ongoing technological changes, especially the development of the Internet. It is thanks to our online activities and the opinions of other Internet users that pro-consumer decisions concerning online purchases are shaped. The article presents the results of empirical studies conducted in 2020 on a sample of 664 respondents using a questionnaire, while the survey results were developed using SPSS Statistics. Findings of research showed the willingness of consumers for prosumption and kind of behaviors that were most often among the research group. In the course of research proceedings, it was possible to define factors that dispose declarative prosumers for the purchase of organic products. Conducted analyses also allowed for building the model of the influence of individual characteristics of respondents on the index of prosumption.
\end{abstract}

Keywords: prosumption; internet; sustainable consumption; consumer; organic products

\section{Introduction}

Today's economic reality has changed the role of modern buyers. They can no longer be described as passive users of goods and services. Thanks to the development of the Internet, they establish relationships with producers and other consumers, while playing the role of Internet prosumers at the same time. This group should therefore be treated as "creative agents" who become important and conscious participants in sustainable consumption.

The aim of the article is to illustrate the specificity of the behavior of Internet prosumers in the organic market. A specific objective of the research was to verify different types of behaviors that may be attributed to consumers perceived as Internet prosumers as well as to determine the factors that most often influence the purchase of organic products. The main hypothesis is that the reviews posted online by other Internet users are helpful in the decision making process for buying organic products, while health factors are decisive for the purchase.

The article is based on an empirical study conducted between March and April 2020 as part of a survey on prosumption attitudes of Polish consumers by means of a questionnaire in accordance with CAWI standards.

\subsection{The Problem and Origins of Prosumption-Theoretical View}

In 1980 Toffler [1] (pp. 53ff and 282ff) in The Third Wave introduced the term prosumer. After the pre-industrial wave when self-sufficiency was the norm and industrial wave that resulted in a mass production and a division between production and consumption, this third wave concerned post-industrial era that tried to rejoin production and consumption 
into prosumption. While Toffler considered prosumption as a category separate from production and consumption, many authors [2-6] publishes numerous articles on the concept and consider both production and consumption as sub-categories of prosumption [7]. For example, to Ritzer [8] (pp. 414-415) and [4] (p. 77), production and consumption create two ends of the 'prosumption continuum'. That means that all activities can be measured as production oriented or consumption oriented prosumption $[4,9]$.

Toffler's view on prosumption is in general positive, underlining that it will strengthen the position of consumers while Ritzer [2] (p. 413) and [4] (p. 90) is very critical explaining that such kind of activity can weaken consumers by over exploiting them and accelerating the hyper consumption.

This somehow relates to the idea of McDonaldisation [5] when customers are put to work and perform as unpaid labor. The examples of this process can be observed in self- service at petrol stations, check-in terminals, and the supermarkets with self-service checkouts and digitalization only speeds this self-service trend [5]. The revolution in information and communication technology (ICT), everyday presence of the Internet and social media have caused an impressive change in access to knowledge [10] or to raw materials and professional equipment from across the globe [11] which blurred the distinction between producers and consumers [12]. For that reason, numerous grassroots movements and public actors established makerspaces and tool libraries to help such development $[11,13]$. Another great example gaining popularity concerns initiatives in energy production for household consumption [14] (p. 135), [15]. Such terms as sharing economy and collaborative consumption can be also used to exemplify the need for a combination of consumer and producer, as consumers themselves produce consumption opportunities for other consumers [16]. New popular concepts of market-supported customer self-production of products and services such as co-creation, co-production or co-innovation [17] suggest that previous differences between producer and consumer are no longer obvious. Undoubtedly modern consumers are no longer seen as people who only consume products and use services. They are no longer just passive and submissive targets of marketing activities. They have become partners of companies in product and service analysis and their marketing activities. They openly assess both the level and the quality of consumer service. One could conclude from this that there is a constant and continuous transfer of knowledge between the company and consumers [18]. Today's businesses are therefore obliged to constantly exchange knowledge with consumers [19] and such transfer is conducted in two directions: from consumers to companies and from companies to consumers [20].

While becoming increasingly aware market participants, consumers are also becoming aware of the discomfort caused by a limitation of their field of activity and by the fact that it has been reduced exclusively to the purchasing aspect. As a result, they express their willingness to participate in other marketing activities. This tendency, duly observed by manufacturers, has led to an increased involvement of buyers in the preparation of marketing offers [21].

A prosumer is defined as a consumer who is involved in business tasks, participates in various activities in the company-customer relationships, and is involved in the transfer of knowledge, the result of which is the sharing of knowledge. Prosumption, on the other hand, is understood as a process in which prosumers are involved in selected productrelated activities, services, and business activities and in which prosumers effectively share their knowledge [21].

Our proprietary definition of prosumption states that it is a continuous process of co-creation of individualized value for the buyer, who has innovation potential (i.e., is involved in the process of creating innovation), participates in the creation of new products and offers, is aware of such an offer (which enables him or her to make an effective purchasing decision), and shares his or her assessment of that offer both online and in the real world. 


\subsection{The Importance of the Internet in the Intensification of Prosumption Processes}

Technological changes (Web 1.0, Web 2.0 and Web 3.0, which are the next stages in the development of the World Wide Web) have had an enormous impact on the development of online prosumption. Access to online resources has grown. There is a wide range of products with impressive capabilities in circulation as a result of access to the Internet. The use of smartwatches, smartphones and tablets also gives us the opportunity to use the Internet on a mobile basis. The result is communication without physical contact, allowing the relationship between the consumer and the company to take place in real time [22]. The almost unlimited accessibility of digital technologies caused that user innovation is no longer limited to end-users and consumers have become involved in co-creating activities with companies [23].

As a result of this process, companies create communication platforms that are a kind of reservoir for creativity and ideas. Should companies leave this path, they would lose their customers, and so they need to be aware of the fact that prosumers often create their own brands and then adapt them to their taste [24]. Especially since the creation of such platforms generates enormous profits and attracts customers who share information about the offer with other customers. As a result of such a discussion concerning the brand, a group of people is formed who are engaged in creating new, innovative ideas that fully meet the needs of prosumers.

The role of the Internet in the development of prosumption is underlined by the fact that prosumers today belong to generations, which places reality in the category of an arena for the creation and exchange of innovative experiences. As Ryder explains [25], generation reflects a cohort of individuals who have responded to the same historical events within the same time and location. Based on different sources $[26,27]$ it is possible to name 20th century generations with the timelines: (1) GIs 1901-1924; (2) Silents 1925-1945; (3) Baby Boomers 1946-1964; (4) Generation X 1965-1980; (5) Generation Y/Millennials 1981-1996; (6) Generation Z/iGens 1997-2010. There also appears (7) Generation Alpha 2010-2025, whose birth year synchronizes with the launch of Instagram and iPad-world's most preferred social media and brand [28].

However, now it is quite hard to state what generation prosumers belong to as differences among different age groups in using Internet begin to fade. Approximately half of the whole world's population are active Internet users and use social media platforms like Twitter or FB [29]. What is more, recent global COVID-19 pandemic and state-enforced residential lockdown has had a dramatic effect on global activities [30] and so the network structure of a prosumed activities has also changed [31]. From entertainment, gaming, connecting to peers, working and education during the COVID-19 pandemic, consumers' lives turn around technology [32].

A new generation of online prosumers is characterized then by a strong need for freedom and freedom of choice. In addition, the new generation of prosumers is tailoring the available offer to their own needs and striving for individualization, dialogue, and entertainment. This generation is characterized by innovation and the tendency to make joint decisions [33].

Most researchers see prosumption as the online activity of buyers who actively use the possibilities of virtual networks. These researchers regard the use of the Internet as a condition for co-designing an offer [34]. In addition, after the prosumer-consumer collaboration became common only in virtual networks, recent advances in digital technologies have led to this phenomenon spreading to the rest of the economy [35].

Some researchers distinguish two forms of activity in the virtual network: Online prosumption and typical network participation. They believe that many activities related to information exchange fall into the second category. A prerequisite for the existence of prosumption is at the same time the need to show creativity [36]. Individuals who can be considered creative form a specific network of users called digitariat. Some [37] believe that users and prosumers cannot work in a virtual network at the same time. They share the belief that modern web applications encourage users to act as prosumers [38]. 
Progressive virtualization of life and universal access to digital technologies brings consumers the opportunity to communicate with other consumers and retailers and to share their opinions about products and brands. This phenomenon is intensifying thanks to the rapid advances in technology, development of knowledge and telecommunication infrastructure. In addition, the nature of content posted on the internet is changing. During the so-called Web 1.0 period, the content of the message posted on the Internet was shaped by the service provider. However, the possibilities of interaction between consumers and producers via the Internet were limited. During Web 2.0, Internet users gained the opportunity to co-create its content, which allowed for the emergence of proconsumer attitudes.

The new technologies not only assist consumers in their fulfilling consumption needs but also allow them to compose value for other consumers. Such co-production activities impel firms to redefine customers' role in the value creation process [39]. The availability of tools allows for the creation of one's own products which enhance consumer activity-cameras, phones, and software. Some of them are made available to consumers by companies. The process of sharing one's own unique ideas and one's creativity is stimulated by the sellers themselves.

Social networks, computing clouds, the grid system, various websites, or Wikipedia are part of the tools that enable the transmission of content and communication between Internet prosumers and sellers. Thanks to them, it is possible to share one's own resources and creativity, to publish slides and documents and to store them in a virtual "cloud".

\subsection{The Concept of Sustainable Consumption}

The development of the global economy, increasing interference in the natural environment, ever scarcer natural resources, and the negative impact of human management on the environment have led to negative effects on human life and health. Under the influence of such changes, the concept of sustainable development has emerged and since the very beginning its importance was considered to have had a great impact on modern world [40]. Sustainable development, known as integrated development or eco-development, determines the model of economic development by combining it with the requirements of environmental protection [41].

This process involves both meeting the needs of the present generation and maintaining the ability to meet the same needs for future generations [42]. It should also be noted that sustainable development recognizes the interdependence of its three integral dimensions - environmental, social, and economic. This is recognized in the revised EU Sustainable Development Strategy [43].

Sustainable consumption is a multidimensional issue. The dimensions that are most often taken into consideration cover environmental, social, and economic sustainability [44]. Due to its complex nature, there is no one definition of sustainable consumption although one of the earliest quoted comes from 1994, when it was defined as "the use of goods and services that respond to basic needs and bring a better quality of life, while minimizing the use of natural resources, toxic materials and emissions of waste and pollutants over the life cycle, so as not to jeopardize the needs of future generations" [45]. In the literature of the subject, the phenomenon of sustainable consumption is usually treated as the concept of "umbrella" which covers such issues as human needs, quality of life, justice, waste minimization, resource efficiency, thinking in terms of product life cycle, health and safety, and consumer sovereignty, etc. see [46].

Some authors believe that "the concept of sustainable consumption should be interpreted as the concept of sustainable development in relation to a specific consumption area" [47]. Others interpret sustainable consumption in a more general way as "a form of its processes that enables the achievement of sustainable development goals" $[48,49]$. New trends and phenomena that are closely linked to the area of consumption offer an interesting basis for considerations on sustainable consumption. This phenomenon is defined 
by some authors in the category of new consumption in the 21st century, which brings unprecedented phenomena and challenges such as the greening of consumption [50].

One of its manifestations is the so-called eco-consumption and ethical consumption. These ideas include the consumption of goods produced by natural methods (e.g., so-called organic food), rational use of consumer goods, renunciation of consumption of goods resulting from cruel practices on animal farms (e.g., cage eggs), recycling of post-consumer waste, and poorly paid work. It should however be emphasized that buying organic products is not necessarily connected with the sustainable consumption, although may be the part of this process. The sustainable consumption and the sustainable production may be associated with promoting a healthy lifestyle and purchasing organic products can contribute to this purpose.

Prosumption can be very much anticipated in the food sector [51], especially when we notice that dependent passive receivers make room for self-supportive active consumers who buy from local farmers, follow diets, purchase organic foods, and engage in prosumption [52].

One thing is for sure-consumption patterns of individual consumers are the main problem of current unsustainable development [53,54].

\section{Materials and Methods}

The research process consisted of two phases: Analysis of the literature and the empirical research, which was divided into stages of preparing research questions, gathering, statistical analysis and drawing conclusions. The empirical research was based on the use of a questionnaire which was sent to Polish adult final purchasers chosen by means of purposive sampling (non-random sampling). Such a sampling was used as it is useful for obtaining data from different groups of people, random sampling is overstated and is not useful for each research process [55] and data gathered are considered to be more representative of the population than with an alternative form of sampling [56]. The minimum sample size was defined as 385 which was calculated at confidence level $\alpha=0.95$ and margin of error $5 \%$ for the population of adult Poles on the basis of data provided on the official site [57].

Sample Size Formula [58] used to calculate the number of sampling was:

$$
\mathrm{n}=\mathrm{z}^{2} \times \mathrm{p} \times(1-\mathrm{p}) / \mathrm{e}^{2}
$$

$\mathrm{n}($ with finite population correction $\left.)=\left[\mathrm{z}^{2} \times \mathrm{p} \times(1-\mathrm{p}) / \mathrm{e}^{2}\right] /\left[1+\left(\mathrm{z}^{2} \times \mathrm{p} \times(1-\mathrm{p}) / \mathrm{e}^{2}\right) /\left(\mathrm{e}^{2} \times \mathrm{N}\right)\right)\right]$

where:

$\mathrm{n}$ is the sample size,

$\mathrm{z}$ is the $\mathrm{z}$-score associated with a level of confidence,

$\mathrm{p}$ is the sample proportion, expressed as a decimal,

$\mathrm{e}$ is the margin of error, expressed as a decimal,

$\mathrm{N}$ is the population size.

A number of research participants larger than the minimum sample size calculated was used to ensure that this minimum size of the sample would be met [59].

The study was conducted in February, March, and April 2020. The questionnaire was completed over the Internet in accordance with CAWI standards. This resulted in a quite fast time of return, 2 months. The research conducted in 2020 was preceded in 2019 by non-structured interviews with 49 people which, together with the results of the literature analysis, allowed to construct a set of questions related to the researched area. According to the fact that the research was conducted under the COVID-19 pandemic, the survey could not have been complemented by personal interviews. Respondents qualified as prosumers must have been characterized by a strong desire of influencing others, willingness to enter into communication, making contacts especially in virtual reality, sharing opinions about products and brands on the Internet asking questions about products and brands in the 
Internet, joining marketing actions on the basis of co-creation of products, advertising slogans or campaigns.

644 correctly completed questionnaires qualified for statistical analysis and the results were compiled using SPSS Statistics software, which is the most widely used software for quantitative data analysis in the social sciences [34]. Thanks to this software, an indepth data analysis could be performed. The analysis helped to identify statistically significant relationships between groups of respondents and to verify the hypotheses. The socio-demographic characteristics of respondents is presented in Table 1.

Table 1. Socio-demographic characteristics of respondents.

\begin{tabular}{|c|c|c|c|c|}
\hline & & Variables & Frequency & Percentage \\
\hline \multirow{2}{*}{1} & \multirow{2}{*}{ Gender } & Male & 205 & 31.83 \\
\hline & & Female & 439 & 68.17 \\
\hline & & Total & 644 & 100 \\
\hline \multirow{5}{*}{2} & \multirow{5}{*}{ Age } & 25 and younger & 257 & 39.91 \\
\hline & & $26-35$ & 161 & 25.00 \\
\hline & & $36-45$ & 128 & 19.87 \\
\hline & & $45+$ & 98 & 15.22 \\
\hline & & Total & 644 & 100 \\
\hline \multirow{5}{*}{3} & \multirow{5}{*}{ Level of education } & Primary education & 3 & 0.46 \\
\hline & & National vocational qualification & 4 & 0.62 \\
\hline & & Secondary education & 186 & 28.88 \\
\hline & & University education & 451 & 70.03 \\
\hline & & Total & 644 & 100 \\
\hline \multirow{3}{*}{4} & \multirow{2}{*}{ Place of residence } & Rural area & 168 & 26.08 \\
\hline & & Urban area & 476 & 73.91 \\
\hline & & Total & 644 & 100 \\
\hline \multirow{3}{*}{5} & \multirow{3}{*}{ Employment status } & Active & 451 & 70.03 \\
\hline & & Non-active & 193 & 29.97 \\
\hline & & Total & 644 & 100 \\
\hline
\end{tabular}

Questions and statements chosen for the questionnaire reflected phrases repeated most often during interviews and were formulated to be unambiguous and clearly understood by respondents. The 5-grade Likert scale was applied in order to rank statements, wheredepending on the statement- 1 indicated definitely no, 2-rather no, 3-hard to say, 4 -rather yes and 5-definitely yes or 1 indicated never, 2-rarely, 3-sometimes, 4-often and 5-always.

An analysis of the online behavior of prosumers in the market for organic products as well as an evaluation of the importance of factors that potentially influence their attitudes and purchasing decisions are the research problem that is dealt with in this article. The following working questions were asked to help in further analyzes:

- What kind of prosumer behavior is most frequently practiced by consumers?

- How often do prosumers follow product reviews published by other Internet users when they make final decisions about buying organic products?

- Are online prosumers able to change their decision to buy organic products solely under the influence of opinions and reviews they read online?

- How often do prosumers urge other Internet users to make decisions about buying organic products based on their own experiences?

- What are the factors that motivate Internet prosumers to buy organic products?

In order to gather data to confirm the research questions, the following research hypotheses were formulated: 
1. Online prosumers often make themselves familiar with the opinions of other Internet users about organic products.

2. Online prosumers formulate their purchasing decisions for organic products on the basis of reviews they read online.

3. Online prosumers influence the decision of internet users to buy organic products by sharing their own experiences.

4. Buying organic products is influenced by various factors, the most important of which is the absence of chemicals in the ingredients of the products.

\section{Results}

On the basis of the analysis of the literature and the non-structured interview, a set of questions and statements related to the researched area was formulated.

The study identified different types of behaviors that can be attributed to online prosumers (see Figure 1).

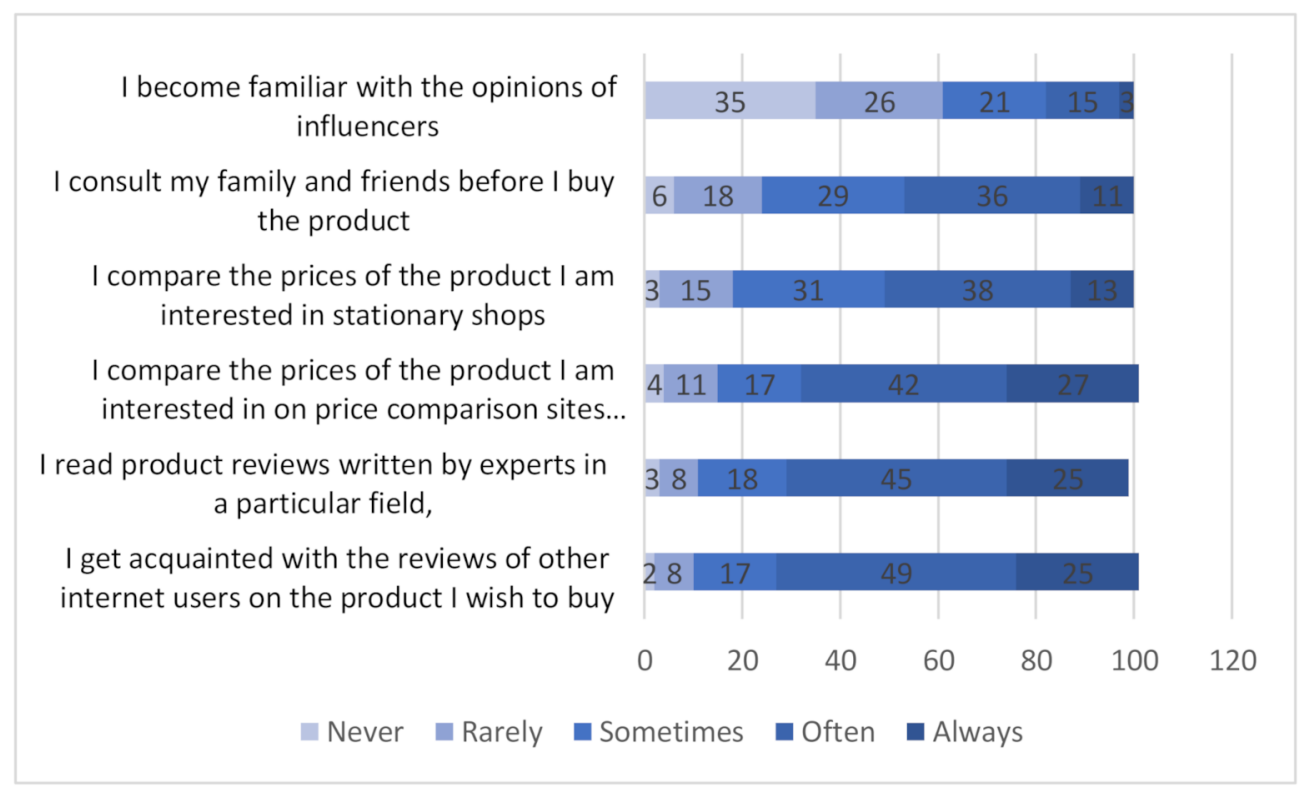

Figure 1. Type and frequency of activities by online prosumers, $\mathrm{N}=664$ (in \%). Source: own.

The majority of respondents indicated that they are familiar with the opinions of other Internet users about products they want to buy. As many as $74 \%$ of respondents do so always or often, while the average score on a scale of 1 to 5 was 3.86. Equally often, respondents indicated that they read product reviews written by experts in a particular field, but also that they compare the prices of the product they are interested in on price comparison websites (averages of 3.82 and 3.76, respectively). On the other hand, respondents read the opinions of influencers much less frequently (only $3 \%$ of respondents always do so, while $35 \%$ never do). In this case, the average score was only 2.25 . Determining the frequency with which prosumers follow product reviews published by other Internet users when they make final decisions about buying organic products was an important element of the research analysis (see Figure 2).

Determining the frequency with which prosumers follow product reviews published by other Internet users when they make final decisions about buying organic products was an important element of the research analysis (see Figure 2). The results show that respondents do this slightly more often than with family and friends. It was found that $43.4 \%$ of the prosumers interviewed often display this type of behavior, $39 \%$ of those interviewed do so from time to time, while $12.2 \%$ rarely do so. The answers "never" and "always" accounted for $2.4 \%$ and $3 \%$ of the indications, respectively. 




Figure 2. Frequency with which prosumers follow product reviews published by other Internet users when they make final decisions about buying organic products, $\mathrm{N}=664$ (in \%). Source: own.

Another point reviewed was the question of changing one's purchasing decision from a product that respondents were determined to buy to one that they were not initially convinced to buy if it was influenced solely by reviews read online (see Figure 3). In terms of respondents' responses, $42.7 \%$ of respondents "rather" or "definitely" had such a situation in the past, while $36.2 \%$ claimed the opposite. Furthermore, $21.1 \%$ of respondents found it difficult to answer the question.



Figure 3. Change in purchasing decision from a product that respondents were determined to buy to a product that they were not initially convinced to buy, influenced exclusively by reviews and reviews read online $\mathrm{N}=664$ (in \%). Source: own.

$42.9 \%$ of respondents stated that they never urge other Internet users to make a decision to buy organic products on the basis of their own experience. Almost a third of the respondents rarely take such measures, while $17.9 \%$ do so from time to time, $5.7 \%$ frequently and $0.3 \%$ always (see Figure 4 ).

Factors that induce Internet prosumers to buy organic products were also examined. An ordinal scale was used for this purpose. It helped to sort the answers according to their importance for the respondents, but also to identify the characteristics with the greatest intensity. These factors were then ranked from the lowest to the highest importance. To do this, the average value of the answers given by the respondents, as shown in Figure 5, was taken into account. 


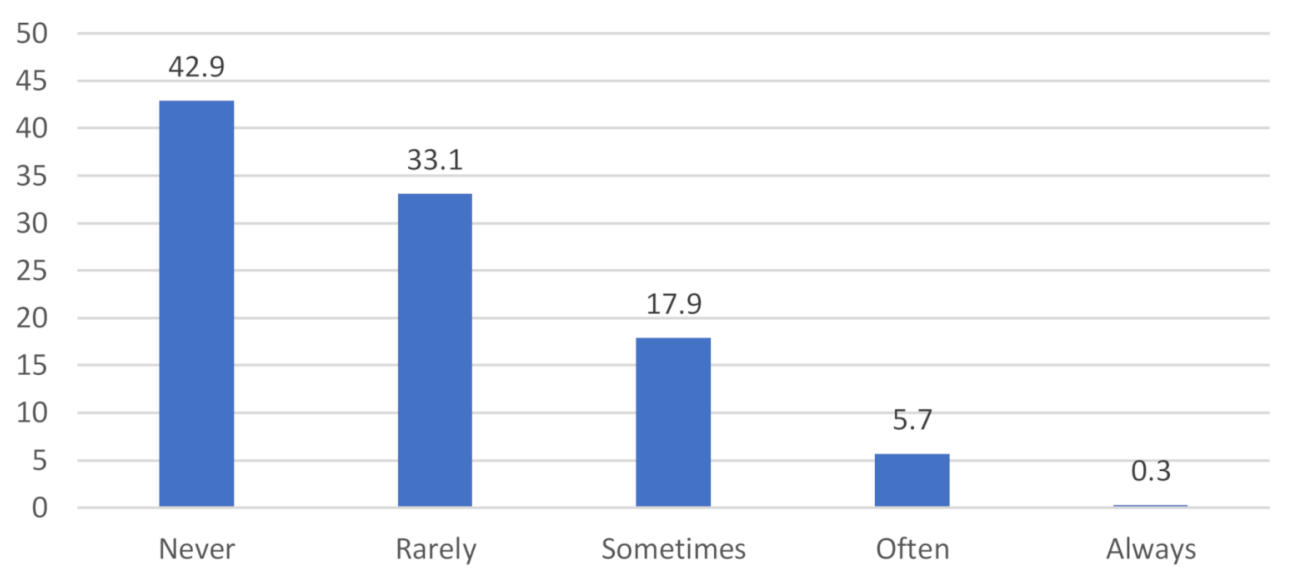

Figure 4. Frequency in which respondents urged other internet users to make a decision to buy organic products based on respondents' own experience $\mathrm{N}=664$ (in \%). Source: own.

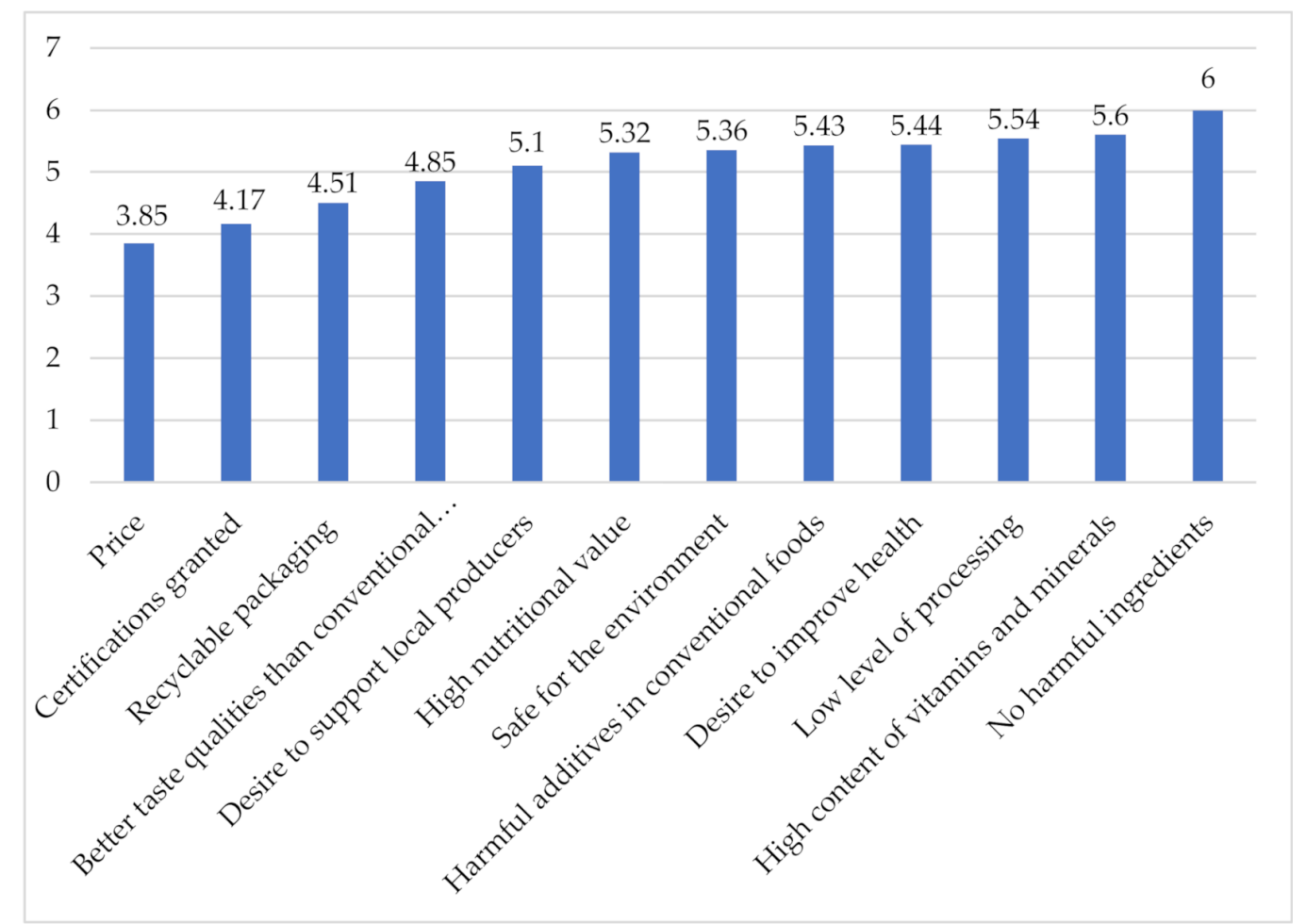

Figure 5. Average of respondents' answers on the importance of factors that induce buying organic products $\mathrm{N}=664$ (in \%). Source: own.

\section{Discussion}

Environmental awareness has increased and has made us realize that in the long run, maintaining the balance leads to maximizing profits. This is how the relationship between environmental, social, and economic governance is shaped. These interdependencies are shown in Figure 6.

The greening of consumption could be the panacea for the damage caused by the overindustrialization of agriculture. Production in organic farming is based on the application of natural production methods to all types of production, i.e., crop growing, animal and fish farming and processing. The greening of food consumption can be seen as a result of increased consumer income and increased interest in the quality of the food consumed. 


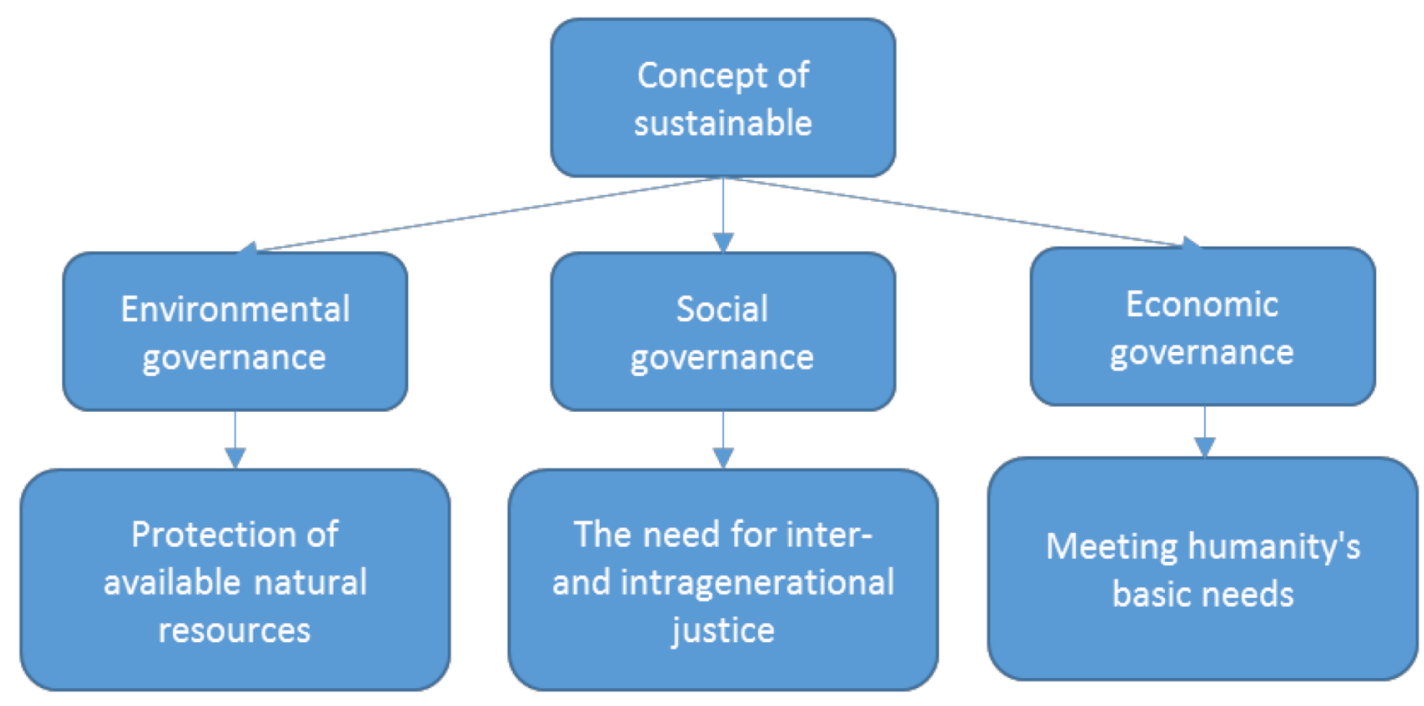

Figure 6. Relationship between environmental, social, and economic governance. Source: own.

Today, there is a growing consumer interest in better food quality. This phenomenon can be explained by consumers' increased environmental awareness, which leads them to take an interest in the impact of the food they eat on their health and the state of the natural environment [15].

The empirical study has shown how important it is to know the factors that actively influence prosumer's behavior on the organic market. The study is particularly important due to the ever-increasing competition. If analyzed correctly, the factors that determine purchasing behavior provide a stable basis for an offer tailored to the needs and expectations of customers, which leads to increased satisfaction with the purchase. This process determines brand loyalty, which can be considered in the context of the repeatability of purchases.

In the course of the research process, it was possible to determine which factors most frequently motivate prosumers to buy organic products. The most important premise for the entire research sample was the absence of chemicals among ingredients of organic products. It was also found that the Internet and the availability of opinions of others are decisive factors in the decision to purchase organic products.

The analysis carried out also made it possible to visualize the influence of individual characteristics of the respondents on the index of prosumption behavior (see Figure 7).

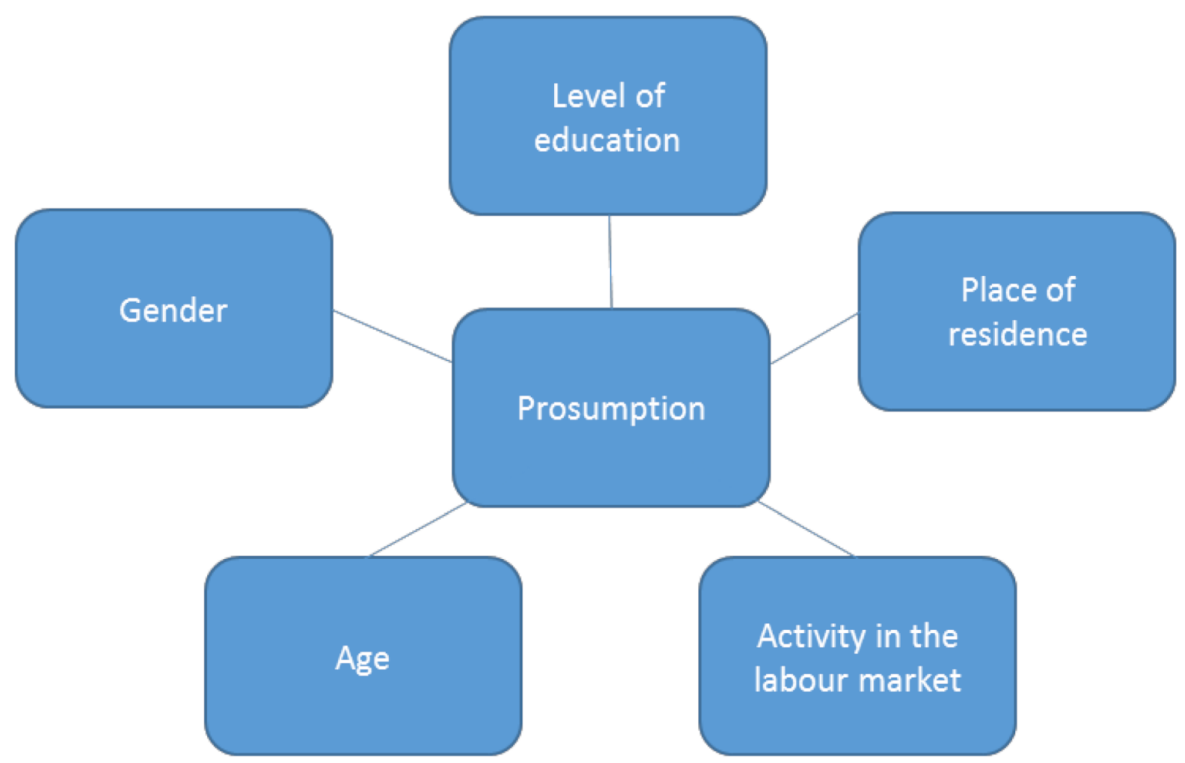

Figure 7. Variables affecting the behavior of online prosumers. Source: own. 
It turns out that attitudes of examined prosumers are largely determined by sociodemographic variables. Table 2 presents chosen aspects of prosumer behaviors determined by gender of respondents.

Table 2. Aspects of prosumer behaviors determined by gender of respondents.

\begin{tabular}{cccccc}
\hline & \multicolumn{2}{c}{ Female N= 439 } & Male N = 205 & \multirow{2}{*}{ Mann-Whitney U Test } \\
\cline { 2 - 4 } & Average & SD & Average & SD & \\
\hline $\begin{array}{c}\text { I consider opinions of other Internet users while } \\
\text { planning the purchase of organic products }\end{array}$ & 4.09 & 1.052 & 3.88 & 1.113 & $42,227.5$ \\
$\begin{array}{c}\text { I describe products and brands and ask about them on } \\
\text { the Internet }\end{array}$ & 2.56 & 1.204 & 2.59 & 1.197 & $47,117.0$ \\
$\begin{array}{c}\text { I am willing to join marketing actions on the basis of } \\
\text { co-creation of products, advertising slogans } \\
\text { or campaigns }\end{array}$ & 1.97 & 1.194 & 2.10 & 1.217 & $44,637.5$ \\
\hline
\end{tabular}

Regarding aspects determined by gender of respondents, statistically significant relations were observed only in case of one variable. Women indeed have more often declared that they take into consideration opinions of other Internet users while making decision of buying organic product.

Table 3 contains information of aspects determined by age, level of education and place of living of respondents.

Table 3. Aspects determined by chosen socio-demographic variables.

\begin{tabular}{|c|c|c|c|c|c|c|}
\hline & \multicolumn{2}{|l|}{ Age } & \multicolumn{2}{|c|}{ Level of Education } & \multicolumn{2}{|c|}{ Place of Living } \\
\hline & Spearman's Rho & $p$ & Spearman's Rho & $p$ & Spearman's Rho & $p$ \\
\hline $\begin{array}{l}\text { I consider opinions of other Internet } \\
\text { users while planning the purchase of } \\
\text { organic products }\end{array}$ & -0.202 & 0.000 & -0.080 & 0.039 & 0.008 & 0.836 \\
\hline $\begin{array}{l}\text { I describe products and brands and } \\
\text { ask about them in the Internet. }\end{array}$ & 0.010 & 0.800 & -0.015 & 0.706 & 0.006 & 0.873 \\
\hline $\begin{array}{l}\text { I am willing to join marketing actions } \\
\text { on the basis of co-creation of products, } \\
\text { advertising slogans or campaigns }\end{array}$ & -0.097 & 0.013 & -0.88 & 0.024 & -0.054 & 0.167 \\
\hline
\end{tabular}

Analyses presented in Table 3 show that along with the age and level of education the declared level of involvement in considering opinions of other Internet users as well as willingness to join marketing actions is decreasing.

The simulations carried out showed also that statistically significant correlations were observed in other three variables. As well, the prevalence of prosumer behavior increases as the frequency of online shopping increases (Spearman's Rho $=0.116, p=0.003$ ) and the duration of daily online activity (Spearman's Rho $=0.081, \mathrm{p}=0.036$ ), but decreases with increasing age of the respondents (Spearman's Rho $=-0.121, \mathrm{p}=0.002$ ).

\section{Limitations of the Study and Further Research}

The research described in this article does not fully exhaust the questions related to the behavior of prosumers on the organic market. Selected factors that encourage potential customers to buy are only basic conditions for closing the deal. In order to predict and control customer behavior, it would be useful to formulate a typology of individual consumers based on established values, motivation, and perception.

The research conducted has serious limitations that include the moment of COVID-19 pandemic and impossibility of direct contact with respondents. In depth interviews with respondents could give additional data for empirical analyses based more on their attitudes. That would also give place to respondents' own suggestions according the organic food 
market. Another inadequacies are limiting the research only to Polish adult consumers and their willingness to prosumption only on the organic market. As well, the level of and willingness to co-operation between consumers and tenderers was not the aim of the study but could be an interesting issue to deal with in further research.

Further research should also include consumers from beyond the borders Poland which would enable international comparative analyses. Possibly the nationality would be a significant variable determining prosumption of the same market. A face-to-face structured interviews with respondents would also be helpful in getting to know their opinions and attitudes towards marketing actions involving them into co-creating marketing offer and product.

Further research on the behavior of online prosumers could attempt to differentiate their behavior according to age, educational background, and place of residence. Qualitative analyzes would also be an interesting proposal, as they would make it possible to uncover hidden, non-parameterized motives of buyer behavior.

\section{Conclusions}

The quantitative analysis of the research carried out and presented in this article made it possible to characterize the phenomenon of prosumption and its individual characteristics. Thanks to the results obtained it was possible to define which prosumption behaviors were the most common and which were sporadic among respondents.

The research positively confirmed all the hypotheses included in this article. It clearly showed that online prosumers often read the opinions of other Internet users about the product they want to buy, read product reviews written by experts in a particular field and compare the prices of the product they were interested in on price comparison sites. As a result, when making decisions about buying organic products, they often let themselves be guided by the opinions of other Internet users and were even able to change such a decision based solely on the opinions and reviews they had read online. The analysis showed that most important factors encouraging Internet prosumers to purchase organic products were lack of harmful ingredients in the product, high content of vitamins and minerals, low level of processing and one's desire to improve health. The least important factor was price. It can be noted then that Internet prosumer were more disposed to buy a more expensive product but characterized by all the mentioned attributes.

At the same time, it was rare to observe that we could get other Internet users to make certain purchasing decisions based on our own experience. It was also rather rare to become familiar with the opinions of influencers.

Consumers eager to participate in the process of creating market offer in any way could become a crucial marketing partner for tenderers by co-creating marketing offers that would better meet purchasers' expectations. In such a way producers could get to know expectations, needs, purchase motives and attitudes of Internet prosumers towards organic products.

All the knowledge, experience and know-how of willing prosumers could diversify and enrich market offers of any branch. A fruitful mutual co-operation between tenderers and co-operative customers should be facilitated by both sides as both sides would benefit from it.

Author Contributions: M.M. and M.K. confirm that their contribution in each stage of the preparation of this article was equal. All authors have read and agreed to the published version of the manuscript.

Funding: This research received no external funding.

Conflicts of Interest: The authors declare no conflict of interest.

\section{References}

1. Toffler, A. The Third Wave; Collins: London, UK, 1980.

2. Ritzer, G. The "New" World of Prosumption: Evolution, "Return of the same”, or Revolution? Sociol. Forum 2015,30 , 1-17. [CrossRef] 
3. Ritzer, G. From production and consumption to prosumption: A personal journey and its larger context. In Routledge Handbook on Consumption; Keller, M., Halkier, B., Wilska, T.A., Eds.; Routledge: London, UK, 2017; pp. 83-93.

4. Ritzer, G. Prosumption: Contemporary Capitalism and the "New" Prosumer. In The Oxford Handbook of Consumption; Wherry, F.F., Woodward, I., Eds.; OUP: Oxford, UK, 2019; pp. 75-93.

5. Ritzer, G.; Miles, S. The changing nature of consumption and the intensification of McDonaldization in the digital age. J. Consum. Cult. 2019, 19, 3-20. [CrossRef]

6. Dusi, D. Beyond prosumer capitalism: Retaining the original understanding of prosumption. Curr. Sociol. 2018, 66, 663-681. [CrossRef]

7. Veen, E.J.; Dagevos, H.; Jansma, J.E. Pragmatic Prosumption: Searching for Food Prosumers in The Netherlands. Sociol. Rural. 2020, 61, 255-277. [CrossRef]

8. Ritzer, G. Prosumer capitalism. Sociol. Q. 2015, 56, 413-445. [CrossRef]

9. Ritzer, G. The McDonaldization of Society: An Investigation into the Changing Character of Contemporary Social Life; Pine Forge Press: Thousand Oaks, CA, USA, 1993.

10. Davis, M. Liquid Sociology: Metaphor in Zygmunt Bauman's Analysis of Modernity; Routledge: London, UK, 2016.

11. Bradley, K. Bike kitchens-Spaces for convivial tools. J. Clean. Prod. 2016, 197, 16-83. [CrossRef]

12. Eden, S. Blurring the boundaries: Prosumption, circularity and online sustainable consumption through Freecycle. J. Consum. Cult. 2017, 17, 265-285. [CrossRef]

13. Lehner, M. Prosumption for sustainable consumption and its implications for sustainable consumption governance. In $A$ Research Agenda for Sustainable Consumption Governance; Edward Elgar Publishing: Camberley, UK, 2019.

14. Rifkin, J. The Zero Marginal Cost Society: The Internet of Things, the Collaborative Commons, and the Collapse of Capitalism; St. Martin's Press: New York, NY, USA, 2014.

15. Hahnel, U.J.; Herberz, M.; Pena-Bello, A.; Parra, D.; Brosch, T. Becoming prosumer: Revealing trading preferences and decisionmaking strategies in peer-to-peer energy communities. Energy Policy 2020, 137, 111098. [CrossRef]

16. Edbring, E.G.; Lehner, M.; Mont, O. Exploring consumer attitudes to alternative models of consumption: Motivations and barriers. J. Clean. Prod. 2016, 123, 5-15. [CrossRef]

17. Roberts, D.; Hughes, M.; Kertbo, K. Exploring consumers' motivations to engage in innovation through co-creation activities. Eur. J. Mark. 2014, 48, 147-169. [CrossRef]

18. Martucci, I.; de Felice, A.; Schirone, D. Knowledge Exchange between IKEA and Suppliers Through Social and Environmental Strategy; European Conference on Knowledge Management; Academic Conferences International Limited: Reading, UK, 2012 ; pp. 699-707.

19. Matschke, C.; Moskaliuk, J.; Cress, U. Knowledge Exchange. Using Web 2.0 Technologies in NGOs. J. Knowl. Manag. 2013, $1,159-176$.

20. McNamee, R.C.; Schoch, N.; Oelschlaeger, P.; Huskey, L. Collaboration Continuum Cultural and Technological Enablers of Knowledge Exchange. Res. Technol. Manag. 2012, 53, 54-57.

21. Smyczek, S.; Sowa, I. Konsument na Rynku. Zachowania, Modele, Aplikacje; Difin: Warszawa, Poland, $2005 ;$ pp. 10-21.

22. Bondos, I. W kierunku Marketingu 3.0. Handel Wewnętrzny 2013, 3, 3-12.

23. Rayna, T.; Striukova, L. Involving consumers: The role of digital technologies in promoting 'prosumption' and user innovation. J. Knowl. Econ. 2016, 1-20. [CrossRef]

24. Trzeciak, D.; Trzeciak, A. Innowacyjny trexy marketing. Mark. Prakt. 2009, 7, 10-14.

25. Ryder, N.B. The Cohort as a Concept in the Study of Social Change. Am. Sociol. Rev. 1965, 30, 843-861. [CrossRef]

26. Tapscott, D.; Barry, B. Grown up Digital: How the Net Generation Is Changing Your World; McGraw-Hill: New York, NY, USA, 2009. Available online: https: / / silo.pub / grown-up-digital-how-the-net-generation-is-changing-your-world.html (accessed on 29 December 2020).

27. McCrindle, M.; Wolfinger, E. The ABC of XYZ: Understanding the Global Generations; McCrindle Research Pty Ltd.: Bella Vista, Australia, 2009. Available online: https://books.google.pl/books?hl=pl\&lr=\&id=BDPHKP31lQEC\&oi=fnd\&pg=PR7\&dq= The+ABC+of+XYZ:+Understanding+the+Global+Generations\&ots=NLDoIPhG7U\&sig=xT1dHMqwJH0fm3dCjqSM0sNiZo\&redir_esc=y\#v=onepage\&q=The $\% 20 \mathrm{ABC} \% 20$ of $\% 20 \mathrm{XYZ} \% 3 \mathrm{~A} \% 20$ Understanding $\% 20$ the $\% 20 \mathrm{Global} \% 20 \mathrm{Generations} \& \mathrm{f}=\mathrm{false}$ (accessed on 30 December 2020).

28. Jha, A.K. Understanding Generation Alpha. 2020. Available online: https:/ / osf.io/d2e8g/ (accessed on 28 December 2020).

29. Alburez-Gutierrez, D.; Aref, S.; Gil-Clavel, B.S.; Grow, A.; Negraia, D.V.; Zagheni, E. Demography in the digital era: New data sources for population research. In Smart Statistics for Smart Applications: Book of Short Papers SIS2019; Arbia, G., Peluso, S., Pini, A., Rivellini, G., Eds.; Pearson: Milano, Italy, 2019; pp. 23-30. Available online: https://osf.io/preprints/socarxiv/24jp7/ (accessed on 30 December 2020).

30. Feldmann, A.; Gasser, O.; Lichtblau, F.; Pujol, E.; Poese, I.; Dietzel, C.; Wagner, D.; Wichtlhuber, M.; Tapiador, J.; Vallina-Rodriguez, N.; et al. The Lock-down Effect: Implications of the COVID-19 Pandemic on Internet Traffic. In Proceedings of the Internet Measurement Conference (IMC, 20), Virtual Event, Pittsburgh, PA, USA, 27-29 October 2020; pp. 1-18. [CrossRef]

31. Bond, A.J.; Widdop, P.; Cockayne, D.; Parnell, D. Prosumption, Networks and Value during a Global Pandemic: Lockdown Leisure and COVID-19. Leis. Sci. 2020, 1-8. [CrossRef]

32. Arora, A.; Jha, A.K.; Alat, P.; Das, S.S. Understanding coronaphobia. Asian J. Psychiatry 2020, 54, 102384. [CrossRef] 
33. Tapscott, D.; Williams, A.D. Wikinomia. O Globalnej Wspótpracy, Która Wszystko Zmienia; Wydawnictwo Akademickie i Profesjonalne: Warszawa, Poland, 2008.

34. Sowa, I. Determinanty zróżnicowań zachowań prosumenckich młodych konsumentów. Studia Ekon. 2015, 231, 120-138.

35. Belk, R. Masz dostęp: Dzielenie się i konsumpcja w trybie współpracy online. J. Bus. Res. 2015, 67, 1595-1600. [CrossRef]

36. Lii, X. Factors influencing the willingness to contribute information to online communities. New Media Soc. 2011, 2, 279-296.

37. Pręgowski, P.; Juza, M. Twórczość w Internecie. Prosumenci, kognitariat, demokratyzacja. Zagadnienia Nauk. 2011, 4, 701-709.

38. Ritzer, G.; Dean, P.; Jurgenson, N. The Coming of the Age of the Prosumer. Am. Behav. Sci. 2012, 4, 379-398. [CrossRef]

39. Dellaert, B.G.C. The consumer production journey: Marketing to consumers as co-producers in the sharing economy. J. Acad. Mark. Sci. 2019, 47, 238-254. [CrossRef]

40. Liu, Y.; Qu, Y.; Lei, Z.; Jia, H. Understanding the evolution of sustainable consumption research. Sustain. Dev. 2017, 25, 414-430. [CrossRef]

41. Griffin, R.W. Fundamentals of Management; Cengage: Boston, MA, USA, 2013.

42. Woźniak, M. Zrównoważony rozwój jako strategia definiująca nowoczesne gospodarowanie przestrzenią w Polsce (aspekty prawne). Ekon. Prawo 2011, 7, 131-132. [CrossRef]

43. Review of the EU Sustainable Development Strategy—Renewed Strategy. Available online: https://www.etuc.org/en/revieweu-sustainable-development-strategy (accessed on 27 December 2020).

44. Social Sustainability: Concepts and Benchmarks. Available online: https://www.europarl.europa.eu/RegData/etudes/ATAG/ 2020/648783/IPOL_ATA(2020)648783_EN.pdf (accessed on 29 December 2020).

45. Sustainable Consumption Helping Consumers Make Eco-Friendly Choices. Available online: https://www.europarl.europa.eu/ RegData/etudes/BRIE/2020/659295/EPRS_BRI(2020)659295_EN.pdf (accessed on 28 December 2020).

46. Mont, O.; Plepys, A. Sustainable consumption progress: Should we be proud or alarmed? J. Clean. Prod. 2008, 16, 532. [CrossRef]

47. Janoś-Kresło, M.; Mróz, B. Konsument i Konsumpcja we Wspótczesnej Gospodarce; Oficyna Wydawnicza SGH w Warszawie: Warszawa, Poland, 2006.

48. Kiełczewski, D. Konsumpcja a Perspektywy Zrównoważonego Rozwoju; Wydawnictwo Uniwersytetu w Białymstoku: Białystok, Poland, 2008.

49. Utzig, M. Zrównoważona konsumpcja w gospodarstwach domowych w Polsce według grup społeczno-ekonomicznych. Konsumpcja i Rozwój 2018, 1, 66-78.

50. Bywalec, C. Konsumpcja a Rozwój Gospodarczy; C.H. Beck: Warszawa, Poland, 2010.

51. Jayaprakash, S.; Ituarte, I.F.; Partanen, J. Prosumer-Driven 3D Food Printing: Role of Digital Platforms in Future 3D Food Printing Systems. In Fundamentals of 3D Food Printing and Applications. In Proceedings of the 2020 IEEE International Conference on Engineering, Technology and Innovation (ICE/ITMC), Cardiff, UK, 15-17 June 2020; Academic Press: Cambridge, MA, USA, 2019 ; pp. 331-354. [CrossRef]

52. Steel, C. Sitopia: How Food Can Save the World; Chatto \& Windus: London, UK, 2020. Available online: https:/ /books.google. pl/books?hl=en\&lr=\&id=NNGqDwAAQBAJ\&oi=fnd\&pg=PT6\&ots=ff $x K O x a A v h \& s i g=y j H z 9662 d o Y u s z W B k 3 k 4 m U B a 2 \_s \&$ redir_esc $=\mathrm{y} \# \mathrm{v}=$ onepage $\& \mathrm{q} \& \mathrm{f}=$ false (accessed on 28 December 2020).

53. Thøgersen, J. Unsustainable consumption. Eur. Psychol. 2014, 19, 84-95. [CrossRef]

54. Rockström, J.; Steffen, W.; Noone, K.; Persson, Å.; Chapin, F.S.; Lambin, E.; Lenton, T.M.; Scheffer, M.; Folke, C.; Schellnhuber, H.J.; et al. Planetary boundaries: Exploring the safe operating space for humanity. Ecol. Soc. 2009, 14. Available online: http://www.jstor. org/stable/26268316 (accessed on 29 December 2020). [CrossRef]

55. Szreder, M. Losowe i nielosowe próby w badaniach statystycznych. Przegląd Stat. 2010, 57, 168-174.

56. Patton, M.Q. Qualitative Research and Evaluation Methods; Sage Publications: Thousand Oaks, CA, USA, 2002.

57. Polska w liczbach. Poland in Numbers. Available online: https://www.polskawliczbach.pl/ (accessed on 29 December 2020).

58. Sample Size Calculator. Available online: https://goodcalculators.com/sample-size-calculator/ (accessed on 22 December 2020).

59. Baruk, A.I. The effect of consumers' ethnocentric attitudes on their willingness for prosumption. Heliyon 2019,5 , e02015. [CrossRef] [PubMed] 